\title{
Analisis Manajemen Transportasi Pada Angkutan Mini Bus
}

\author{
Rahmi Sarafina ${ }^{1 *}$, Bukhari Usman ${ }^{1}$, Yulfitra Adamy ${ }^{2}$ \\ ${ }^{1}$ Program Studi Manajemen, Fakultas Ekonomi, Universitas Abulyatama, Aceh Besar, 23372, \\ Indonesia. \\ ${ }^{2}$ Program Studi Ekonomi Pembangunan, Fakultas Ekonomi, Universitas Abulyatama, Aceh Besar, \\ 23372, Indonesia. \\ *Email korespondensi: fduyana@gmail.com \\ Diterima 19 Desember 2019; Disetujui 15 Maret 2019; Dipublikasi 30 April 2019

\begin{abstract}
This study aims to analyze the management of mini bus transportation at PT. Mulia Wisata Perkasa Banda Aceh which is seen in terms of strengths, weaknesses, opportunities and obstacles. The research is descriptive and uses primary data as a source of data obtained through interviews with respondents. Data analysis using SWOT methods and cartesius diagrams. The results of the study show that the right strategy is applied to PT. Mulia Wisata Perkasa is currently implementing the SO (strength and Opportunities) strategy, with strength 2 and opportunites 1.63. Based on the Cartesian diagram, PT. Mulia opportunities) are carried out to utilize the company's strengths to capture the opportunities that the company has. The strategy pursued through efforts to provide promotion to the desired consumer market, providing quality assurance for the products (services) offered, and providing maximum service to consumers.
\end{abstract} \\ Wisata Perkasa has been on the right track by continuing to strategy growth. SO strategies (strength and
}

Keywords: transportation, management, SWOT.

\begin{abstract}
Abstrak: Penelitian ini bertujuan untuk menganalisis manajemen transportasi mini bus pada PT. Mulia Wisata Perkasa Banda Aceh yang dilihat dari sisi kekuatan, kelemahan, peluang dan hambatan. Penelitian bersifat deskriptif dan menggunakan data primer sebagai sumber data yang diperoleh melalui wawancara dengan responden. Analisis data menggunakan metode SWOT dan diagram cartesius. Hasil penelitian menunjukan bahwa Strategi yang tepat diterapkan pada PT. Mulia Wisata Perkasa untuk saat ini adalah menerapkan strategi SO (strength dan Opportunities), dengan nilai strength 2 dan opportunites 1,63. Berdasarkan diagram cartesius, PT. Mulia Wisata Perkasa telah berada pada jalur yang tepat dengan terus melakukan strategi growth (pertumbuhan). Strategi SO (strength dan opportunities) dilakukan untuk memanfaatkan kekuatan perusahaan guna menangkap peluang yang dimiliki perusahaan. Strategi yang ditempuh melalui upaya memberikan promosi pada pasar konsumen yang diinginkan, memberikan jaminan kualitas terhadap produk (jasa) yang ditawarkan, dan memberikan pelayanan yang maksimal kepada konsumen.
\end{abstract}

Kata kunci : transportasi, manajemen, SWOT 
Pada era globalisasi ini, transportasi merupakan sarana yang dapat meningkatkan pendapatan nasional serta pertahanan dan keamanan nasional. Hal tersebut menujukkan bahwa pentingnya transportasi di Indonesia, sehingga pembangunan dan peningkatan kualitas pelayanan transportasi atau pengangkutan mutlak diperlukan, pembangunan yang baik dan berkualitas tidak hanya mengenai peningkatan mutu sarananya saja, tetapi juga harus menyangkut pembangunan aspek hukum transportasi sendiri. Pembangunan hukum tidak hanya menambah peraturan baru atau merubah peraturan lama dengan peraturan baru tetapi juga harus dapat memberikan kepastian dan perlindungan hukum bagi semua pihak yang terkait dengan sistem transportasi terutama pengguna jasa transportasi (Nugroho, 2008:17).

Transportasi yang ada di negara-negara yang sedang berkembang sangat penting di daerah-daerah pedesaan karena menyediakan akses bagi masyarakat desa untuk memenuhi kebutuhan dan jasa sehari-hari, serta meningkatkan kehidupan sosial ekonomi. Akses terhadap informasi, pasar dan jasa masyarakat, lokasi tertentu, serta peluang-peluang baru kesemuanya merupakan kebutuhan yang penting dalam proses pembangunan (Nasution, 2004:13).

Dalam Undang-Undang Nomor 22 Tahun 2009 tentang Lalu Lintas dan Angkutan Jalan Pasal 186 mengenai kewajiban pengangkutan kepada penumpang atau barang "Perusahaan angkutan umum wajib mengangkut orang dan/atau barang setelah disepakati perjanjian angkutan dan/atau barang setelah disepakati perjanjian angkutan dan/atau dilakukan pembayaran biaya pengangkutan oleh penumpang dan/atau pengirim barang.

Transportasi merupakan salah satu fasilitas bagi suatu daerah untuk maju dan berkembang serta transportasi dapat meningkatkan aksesibilitas atau hubungan suatu daerah karena aksesibilitas sering dikaitkan dengan daerah. Untuk membangun suatu pedesaan, keberadaan prasarana dan sarana transportasi tidak dapat terpisahkan dalam suatu program pembangunan (Andriasnyah, 2015:2).

Jarak yang ditempuh dari kawasan Banda Aceh sampai ke Sigli, Bireuen, Lhokseumawe, Panton Labu, Idi, Langsa, Kuala Simpang, Takengon merupakan tempat berlangsungnya kegiatan ekonomi, sosial ataupun kegiatan lainnya. Kegiatan ini mengharuskan manusia untuk melakukan pergerakan atau perjalanan yang menggunakan transportasi yang melibatkan sarana dan prasarananya. Di antara satu jenis angkutan umum yang sering melewati kawasan tersebut diatas adalah minibus. Angkutan umum serta prasarananya harus mampu memberikan pelayanan yang baik kepada penumpang yang berawal dari terminal Kota Banda Aceh dan berakhir atau bertujuan ke terminal tempat trayek mini bus beroperasi.

Dalam beroperasi dilapangan, terkadang minibus menaikkan penumpang di luar batas kapasitasnya, waktu keberangkatannya tidak sesuai, ketika mengendarai mini bus terlalu cepat sehingga membuat penumpang merasa takut dan tidak nyaman serta lama berhenti ditempat pemberhentian untuk menunggu penumpang. Begitu pentingnya transportasi bagi 
kehidupan manusia, maka perlu dilakukan pengelolaan atau manajemen transportasi yang baik.

Perusahaan angkutan PT. Mulia Wisata Perkasa merupakan suatu perusahaan pengangkutan penumpang yang berkedudukan dijalan Teungku Imum Leung Bata No.3 Komplek Terminal Lueng Bata Banda Aceh, dengan melayani trayek Banda Aceh - Sigli Bireuen - Lhokseumawe - Panton Labu - Idi Langsa - Kuala Simpang - Takengon. PT. Mulia Wisata Perkasa Banda Aceh telah berdiri sejak tahun 2006. Pada awalnya perusahaan ini berdiri dengan nama CV. Mulia Wisata Taksi namun sejak tahun 2013 perusahaan tersebut berubah nama menjadi PT. Mulia Wisata Perkasa.

Kompetensi khusus yang terdapat dalam PT. Mulia Wisata Perkasa Banda Aceh yang berakibat pada kepemilikan keunggulan komparatif. Keterbatasan, keterampilan dan kemampuan yang menjadi penghalang bagi kinerja perusahaan. Kesempatan yang biasanya tidak datang berulang-ulang dan dalam waktu yang sangat singkat, sehingga diperlukan antisipasi dan waktu yang tepat serta kecenderungan lingkungan yang tidak menguntungkan dapat merugikan posisi perusahaan.

\section{KAJIAN PUSTAKA}

\section{Manajemen}

Menurut Hasibuan (2007:2) manajemen adalah ilmu dan seni dalam mengatur proses pemanfaatan sumber daya manusia dan sumbersumber lainnya secara efektif dan efisien untuk mencapai tujuan. Sedangkan menurut Solihin Analisis Manajemen Transportasi....

(Sarafina, Usman, \& Adamy, 2019)
(2009:3) manajemen adalah bagaimana manajer dapat mengenali peran dan pentingnya para pihak yang akan menunjang pencapaian tujuan perusahaan. Para menajer harus mengakui bahwa mereka tidak akan dapat mencapa tujuan perusahaan seorang diri, melainkan melalui kerja sama dengan orang lain.

Menurut Manullang (2006:5) Manajemen adalah seni dan ilmu perencanaan, pengorganisasian, penyusunan, pengarahan dan pengawasan sumber daya untuk mencapai tujuan yang sudah ditetapkan. Sedangkan Silalahi (2011:7) mendefinisikan bahwa manajemen sebagai proses perencanaan, pengorganisasian, pengatur sumber daya, pengomunikasian, pemimpinan, pemotivasian, dan pengendalian pelaksanaan tugas-tugas dan penggunaan sumber-sumber untuk mencapai tujuan organisasional secara efektif dan secara efesien.

Menurut Hasibuan (2007:3) ada beberapa fungsi manajemen antara lain sebagai berikut :

1. Perencanaan, yaitu proses menentukan sasaran organisasi dan sasaran untuk mencapainya.

2. Mengorganisasikan, yaitu suatu proses dimana menetapkan suatu keputusan yang akan dibuat, siapa yang melakukan pekerjaan dan siapa yang akan bekerja.

3. Pengarahan, yaitu fungsi dari kepemimpinan manajer untuk meningkatkan efektifitas dan efisiensi kerja secara maksimal serta menciptakan lingkungan kerja yang sehat, dinamis, dan lain sebagainya.

4. Mengendalikan, yaitu mengontrol atau mengawasi pekerjaan yang dilakukan 
sebelumnya apakah sudah sesuai dengan tujuan yang telah ditetapkan sebelumnya atau belum.

Menurut Terry (2010:9), fungsi manajemen dapat dibagi menjadi 4 (empat) bagian, yaitu

1. Perencanaan (Plannning), ialah penetapan pekerjaan yang harus dilaksanakan oleh kelompok untuk mencapai tujuan yang digariskan. Planning mencakup kegiatan pengambilan keputusan, karena termasuk dalam pemilihan alternatifalternatif keputusan. Diperlukan kemampuan untuk mengadakan visualisasi dan melihatke depan guna merumuskan suatu pola dari himpunan tindakan untuk masa mendatang.

2. Pengorganisasian (Organizing), ialah untuk menghimpun dan mengatur semua sumber-sumber yang diperlukan, termasuk manusia, sehingga pekerjaan yang dikehendaki dapat dilaksanakan dengan berhasil.

3. Pelaksanaan (Aktuating), ialah untuk menghimpun dan mengatur semua sumber-sumber yang diperlukan, termasuk manusia, sehingga pekerjaan yang dikehendaki dapat dilaksanakan dengan berhasil.

4. Pengawasan (Controlling), ialah penemuan dan penerapan cara dan alat utk menjamin bahwa rencana telah dilaksanakan sesuai dengan rencana yang telah ditetapkan.

\section{Transportasi}

Transportasi berasal dari bahasa latin yaitu tranportare, dimana trans berarti seberang atau sebelah lain dan portare yang berarti pengangkutan, transportasi berarti pengangkutan atau membawa sesuatu kesebelah lain dari suatu tempat ketempat lain melalui jalur darat (Ratnasari dan Mastuti, 2011:13). Sedangkan menurut Andriansyah (2015:1), transportasi adalah pemindahan manusia atau barang dengan menggunakan wahana yang digerakkan oleh manusia atau mesin. Transportasi digunakan untuk memudahkan manusia untuk melakukan aktivitas sehari-hari.

Menurut Nasution (2004:13) transportasi yang ada di negara-negara yang sedang berkembang sangat penting di daerah-daerah pedesaan karena menyediakan akses bagi masyarakat desa untuk memenuhi kebutuhan dan jasa sehari-hari, serta meningkatkan kehidupan sosial ekonomi. Akses terhadap informasi, pasar dan jasa masyarakat, lokasi tertentu, serta peluang-peluang baru kesemuanya merupakan kebutuhan yang penting dalam proses pembangunan.

Menurut Marpiani (2011:13) transportasi adalah suatu jenis kegiatan yang menyangkut peningkatan kebutuhan manusia dengan mengubah letak geografis orang maupun barang. Dengan transportasi bahan baku dibawa menuju tempat produksi dan dengan transportasi jugalah hasil produksi dibawa kepasar atau ketempat pelayanan kebutuhan.

Menurut Kamaluddin (2003:15) peran transportasi hanya untuk melancarkan arus barang dan mobilitas manusia. Transportasi juga 
membantu tercapainya pengalokasian sumbersumber ekonomi secara optimal dan jasa transportasi harus cukup tersedia secara merata dan terjangkau oleh daya beli masyarakat. Aktifitas masyarakat yang menyangkut dengan produksi barang dan jasa untuk mencukupi kebutuhannya yang beraneka ragam. Oleh sebab itu, manfaat transportasi dapat juga dilihat daris segi kehidupan masyarakat yang dapat berperan dalam beberapa hal antara lain peran ekonomi.

Menurut Dony Purnomo dalam Sukarto (2006:94-95), transportasi memiliki berbagai manfaat bagi kehidupan manusia yaitu manfaat sosial yaitu dalam kehidupan sosial/ bermasyarakat ada bentuk hubungan yang bersifat resmi, seperti hubungan antara lembaga pemerintah dengan swasta, maupun hubungan yang bersifat tidak resmi, seperti hubungan keluarga, sahabat, dan sebagainya. Kemudian, manfaat Ekonomi, yaitu manusia memanfaatkan sumberdaya alam untuk memenuhi kebutuhan pangan, sandang, dan papan. Sumberdaya alam ini perlu diolah melalui proses produksi untuk menjadi bahan siap pakai untuk dipasarkan, sehingga selanjutnya terjadi proses tukar menukar antara penjual dan pembeli. Lebih lanjut, manfaat Politik, yaitu a) Transportasi menciptakan persatuan nasional yang semakin kuat dengan meniadakan isolasi. b) Transportasi mengakibatkan pelayanan kepada masyarakat dapat dikembangkan atau diperluas secara lebih merata. c) Keamanan negara sangat tergantung pada transportasi yang efisien untuk memudahkan mobilisasi kemampuan dan ketahanan nasional, serta memungkinkan perpindahan pasukan selama masa perang atau Analisis Manajemen Transportasi...

(Sarafina, Usman, \& Adamy, 2019) untuk menjaga keamanan dalam negeri. d) Sistem transportasi yang efisien memungkinkan perpindahan penduduk dari daerah bencana. Semenyara itu manfaat fisik, yaitu transportasi mendukung perkembangan kota dan wilayah sebagai sarana penghubung.

Menurut Setiani (2015:104), terdapat beberapa jenis transportasi yaitu sebagai berikut:

1. Transportasi darat, yaitu kendaraan bermotor, kereta api, gerobak yang ditarik oleh hewan (kuda, sapi, kerbau) atau manusia. Moda transportasi darat dipilh berdasarkan faktor-faktor seperti jenis dan spesifikasi kendaraan, jarak perjalanan, tujuan perjalanan, ketersediaan moda, ukuran kota dan kerapatan permukiman, faktor sosial ekonomi.

2. Transportasi air (sungai, danau, laut), yaitu kapal, tongkang, perahu, rakit.

3. Transportasi udara (pesawat terbang), yaitu transportasi udara dapat menjangkau tempat-tempat yang tidak dapat ditempuh dengan moda darat atau laut, disamping mampu bergerak lebih cepat dan mempunyai lintasan yang lurus, serta praktis bebas hambatan.

\section{Manajemen Transportasi}

Menurut Andriansyah (2015:19) sistem manajemen transportasi (transportation management system) adalah rangkaian sistem atau pengelolaan terhadap moda transportasi oleh suatu kelompok atau golongan.Karena begitu pentingnya transportasi bagi kehidupan manusia, maka perlu dilakukan pengelolaan atau 
manajemen transportasi yang baik. Pada umunya, manajemen transportasi menghadapi tiga tugas utama:

1. Menyusun rencana dan program untuk mencapai tujuan dan misi organisasi secara keseluruhan.

2. Meningkatkan produktivitas dan kinerja perusahaan.

3. Mengoperasikan angkutan secara garis besar.

Menurut Nasution (2004:107), bagi perusahaan- perusahaan transportasi umum yang menghasilkan jasa pelayanan transportasi kepada masyarakat pemakai jasa angkutan (users), maka pada prinsipnya terdapat empat fungsi produk jasa transportasi yaitu aman (safety), tertib dan teratur (regularity), nyaman (confort) dan ekonomis. Untuk mewujudkan keempat fungsi produk jasa transportasi tersebut, fungsi manajemen transportasi bagi perusahaan transportasi pada umumnya adalah :

1. Merencanakan kapasitas dan jumlah armada.

2. Merencanakan jaringan trayek atau rute serta menentukan jadwal keberangkatan

3. Mengatur pelaksanaan operasi armada dan awak kendaraan.

4. Memelihara dan memperbaiki armada.

5. Melaksanakan promosi dan penjualan tiket.

6. Merencanakan dan mengendalikan keuangan.

7. Mengatur pembelian suku cadang dan logistik.
8. Merencanakan sistem dan prosedur untuk meningkatkan efesiensi perusahaan.

9. Melaksanakan penelitian dan pengembangan perusahaan.

10. Menjalin hubungan yang erat dengan instansi-instansi pemerintah maupun instansi lainnya yang terkait.

Menurut Rudi Hermawan (2001:55) untuk mengukur tingkat keberhasilan atau kinerja dari sistem operasi transportasi ada beberapa parameter/indikator yang bisa dilihat, yaitu faktor tingkat pelayanan dan kualitas Pelayanan. Kualitas pelayanan mencakup keselamatan, keandalan, fleksibilitas, kenyamanan, kecepatan, dan dampak.

\section{METODE PENELITIAN}

Objek penelitian dalam penelitian ini mengenai manajemen transportasi yang berada di wilayah Kota Banda Aceh. Penelitian dilakukan pada PT. Mulia Wisata Perkasa Banda Aceh. Lokasi penelitian dilakukan di Jl. Teungku Imum Lueng Bata No.3 Komplek Terminal Leung Bata Banda Aceh.

Jenis penelitian bersifat deskriptif yang dipadukan dengan landasan teori agar fokus penelitian sesuai dengan fakta dilapangan. Selain itu landasan teori juga bermanfaat untuk memberikan gambaran umum tentang latar penelitian dan sebagai bahan pembahasan hasil penelitian.

Beberapa metode pengumpulan data, yaitu :

1. Penelitian lapangan, yaitu suatu penelitian yang dilakukan secara langsung pada objeknya yaitu pada 
aktivitas dilapangan dan perusahaan PT.

Mulia Wisata Perkasa Banda Aceh, dengan cara :

a. Observasi, yaitu metode pengumpulan data dengan cara mengamati, mencatat dan memantau secara langsung pada aktivitas yang berhubungan dengan perusahaan tersebut.

b. Wawancara, yaitu metode pengumpulan data dengan mengadakan tanya jawab dengan objek penelitian, yaitu para karyawan dan supir sebanyak 22 orang.

2. Penelitian kepustakaan, yaitu suatu metode pengumpulan data dengan mengunjungi pustakaan untuk membaca berupa buku-buku, mencatat perihal penting yang berhubungan dengan penelitian.

Penyusunan skala pengukuran dengan alternatif pilihan, meliputi faktor kekuatan dan peluang, dengan nilai Sangat Baik (SB) : 4, Baik (B) : 3, Cukup (C) : 2, Tidak Baik (TB) : 1 . Untuk faktor kelemahan dan ancaman, dengan nilai Sangat Tinggi (ST) : 1, Tinggi (T) : 2, Cukup (C) : 3, dan Rendah (R) : 4.

Analisis data menggunakan Metode SWOT. Menurut Rangkuti (2006:29) analisis SWOT adalah identifikasi berbagai faktor secara sistematis untuk merumuskan strategi perusahaan. Analisis ini didasarkan pada logika yang dapat memaksimalkan kekuatan (strengths) dan peluang oppurtunities, namun secara bersamaan dapat meminimalkan kelemahan Analisis Manajemen Transportasi...

(Sarafina, Usman, \& Adamy, 2019) (weakness) dan ancaman (threats). Proses pengambilan keputusan dengan cara ini selalu dikaitkan dengan pengembangan misi, tujuan, strategi dan kebijakan usaha. Jadi pada prinsipnya analisis SWOT membandingkan antara faktor eksternal (peluang dan ancaman) dan faktor internal (kekuatan dan kelemahan) guna menetapkan formulasi strategi (perencanaan strategi) dalam upaya penyusunan strategi jangka panjang.

Tabel 1. Analisis SWOT

\begin{tabular}{|c|c|c|}
\hline SW & $\begin{array}{c}\text { Strengths } \\
\text { Faktor } \\
\text { Kekuatan } \\
\text { Internal }\end{array}$ & $\begin{array}{r}\text { Weeakness } \\
\text { Faktor } \\
\text { Kekuatan } \\
\text { Eksternal }\end{array}$ \\
\hline $\begin{array}{c}\text { Faktor } \\
\text { Peluang Eksternal }\end{array}$ & $\begin{array}{c}\text { Strategi SO } \\
\text { Menggunaka } \\
\text { n kekuatan } \\
\text { untuk } \\
\text { memanfaatkan } \\
\text { peluang }\end{array}$ & $\begin{array}{c}\text { Strategi WO } \\
\text { Ciptakan } \\
\text { strategi yang } \\
\text { meminimalkan } \\
\text { kelemahan untuk } \\
\text { memanfaatkan } \\
\text { peluang }\end{array}$ \\
\hline $\begin{array}{l}\text { Fakto-faktor } \\
\text { ancaman } \\
\text { eksternal }\end{array}$ & $\begin{array}{c}\text { Strategi ST } \\
\text { Ciptakan } \\
\text { strategi yang } \\
\text { menggunakan } \\
\text { kekuatan untuk } \\
\text { mengatasi } \\
\text { ancaman }\end{array}$ & $\begin{array}{c}\text { Strategi WT } \\
\text { Ciptakan } \\
\text { strategi yang } \\
\text { meminimalkan } \\
\text { kelemahan dan } \\
\text { menghindari } \\
\text { ancaman }\end{array}$ \\
\hline
\end{tabular}

Sumber : Rangkuti, 2006

Kemudian analisis SWOT yang dilakukan dapat menghasilkan 4 (empat) kemungkinan strategi alternatif yang dapat dilakukan (Rangkuti, 2006:45), yaitu :

1. Strategi Strenghts-Oppurtunities(S-O), strategi ini direncanakan berdasarkan jalan pikiran perusahaan, yaitu dengan memaksimalkan seluruh kekuatan dan memanfaatkan peluang yang ada dengan sebesar-besarnya. 
2. Strategi Weakness-Oppurtunities (W-O), strategi ini dibuat untuk memanfaatkan peluang yang ada dengan sebesarbesarnya dengan mengatasi kelemahankelemahan yang dimiliki pada perusahaan tersebut.

3. Strategi Strenghts-Threats (S-T), strategi ini diterapkan dengan menggunakan kekuatan yang dimiliki untuk mengatasi ancaman yang ada diluar.

4. Strategi Weakness-Threats (W-T), strategi ini dibuat berdasarkan pada kegiatan yang bersifat bertahan (defensive) dan berusaha untuk meminimalkan kelemahan serta menghindari ancaman yang ada diluar.

\section{HASIL DAN PEMBAHASAN}

\section{Sejarah PT. Mulia Wisata Perkasa Banda} Aceh

PT. Mulia Wisata Perkasa Banda Aceh pertama kali berdiri pada tahun 2006 dengan nama CV. Mulia Wisata Taxi sebagai perusahaan travel di Banda Aceh. Pada tahun 2013 berubah menjadi PT. Mulia Wisata Perkasa yang lebih fokus menangani keperluan pelayanan jasa angkutan penumpang dan pengiriman barang dari dalam maupun diluar Banda Aceh.

Perusahaan ini telah berdiri selama 13 tahun dan sudah memiliki banyak perkembangan, baik dari bertambahnya jumlah karyawan maupun bertambahnya mobil angkutan penumpang. Dalam perjalanannya PT. Mulia Wisata Perkasa berkembang pesat bukan hanya dalam pelayanan jasa tetapi menambah kebidang pengiriman barang. Selain di Banda Aceh, PT. Mulia Wisata Perkasa juga memiliki cabang lainnya yang berada di Sigli, Bireun, Lhokseumawe, Panton Labu, Idi, Langsa, Kuala Simpang, Medan dan Takengon.

Visi PT. Mulia Wisata Perkasa adalah menjadi perusahaan jasa yang peduli terhadap karyawan, lingkungan dan masyarakat serta memberikan layanan transportasi yang berkualitas terhadap masyarakat. Sedangkan misi PT. Mulia Wisata Perkasa adalah memberikan kenyamanan dan keamanan penumpang dengan menggunakan armada mini bus dan meningkatkan kepuasan pelanggan dengan menetapkan kualitas yang terbaik.

\section{Deskripsi Responden}

Berdasarkan status, diketahui bahwa responden yang sudah menikah sebanyak 17 orang dan responden yang belum menikah adalah sebanyak 5 orang. Jadi, responden yang sudah menikah adalah yang paling banyak dalam penelitian ini yaitu sebanyak 17 orang atau 77,3 persen. Dari sisi usia, responden yang berusia 20 sampai 30 tahun sebanyak 6 orang, responden yang berusia 31 sampai 40 tahun sebanyak 4 orang, responden yang berusia 41 ssampai 50 tahun sebanyak 11 orang dan responden yang berusia diatas 50 tahun sebanyak 1 orang. Jadi, responden yang paling banyak dalam penelitian ini adalah responden yang berusia kurang dari 41 sampai 50 tahun yaitu sebanyak 11 orang atau 50,0 persen.

Sementara itu, berdasarkan pendidikan bahwa responden yang berpendidikan Sekolah Menengah Pertama sebanyak 3 orang, yang 
berpendidikan Sekolah Menengah Atas sebanyak 13 orang dan yang berpendidikan Sarjana sebanyak 6 orang. Jadi, responden yang berpendidikan Sekolah Menengah Atas adalah yang paling banyak dalam penelitian ini yaitu sebanyak 13 orang atau 59,1 persen. Adapun berdasarkan pengalamaan kerja, responden yang bekerja selama 1 tahun sebanyak 2 orang, yang bekerja selama 2 tahun sebanyak 7 orang, yang bekerja selama 3 tahun sebanyak 3 orang, yang bekerja selama 4 tahun sebanyak 2 orang dan yang bekerja lebih dari 5 tahun sebanyak 8 orang. Jadi responden yang bekerja lebih dari 5 tahun yang paling banyak dalam penelitian ini yaitu sebanyak 8 orang atau 36,4 persen.

\section{Analisis Lingkungan Internal dan Eksternal}

Analisis lingkungan internal PT. Mulia Wisata Perkasa antara lain :

1. Produk PT. Mulia Wisata Perkasa Kualitas produk yang diberikan menjadi peran penting terhadap kepuasan pelanggan dan akan berdampak positif serta mendapatkan citra baik bagi perusahaan. Produk yang terdapat di PT. Mulia Wisata Perkasa adalah Mini Bus. Mini Bus yang mengangkut penumpang dari Banda Aceh, Sigli, Bireun, Lhokseumawe, Panton Labu, Idi, Langsa, Kuala Simpang, Medan dan Takengon. Mini Bus yang digunakan adalah kendaraan yang kualitasnya masih terjamin yakni dengan usia kendaraan dibawah 5 tahun.

2. Harga Produk Dalam menentukan harga, PT. Mulia
Wisata Perkasa menyesuaikan dengan harga yang ditawarkan oleh perusahaan lainnya, sehingga tidak mendapatkan citra buruk di mata para konsumen dan PT. Mulia Wisata Perkasa tetap mendapatkan keuntungan seperti yang didapatkan oleh perusahaan lainnya.

\section{Pelayanan Penumpang}

Dalam memberikan pelayanan terhadap penumpang, PT. Mulia Wisata Perkasa memberikan pelayanan yang bagus, baik, ramah, memberikan jasa antar jemput bagi penumpang tidak perlu menunggu diloket dan menyediakan mini bus yang nyaman (AC) dan bagi penumpang yang terbiasa merokok bisa memilih mini bus yang non AC.

Sedangkan analisis lingkungan eksternal PT. Mulia Wisata Perkasa adalah :

\section{Persaingan}

Adanya pesaing liar yang kendaraannya tidak masuk loket atau terminal dan agen liar yang berkeliaran menjadi pesaing yang harus di waspadai.PT. Mulia Wisata Perkasa harus memberikan jasa yang lebih agar mampu berdiri kokoh dan berkembang ditengah banyaknya pesaing usaha jasa transportasi.

\section{Kebijakan Pemerintah}

Kebijakan yang diterbitkan oleh Pemerintah dapat berpengaruh bagi pengoperasian Mini Bus PT. Mulia Wisata Perkasa.Dengan meningkatkan harga BBM, perusahaan menjadi lemah atau dilema dalam menentukan harga yang ditawarkan. 


\section{Teknologi}

Di dunia globalisasi ini, perkembangan teknologi dapat mempermudah pelayanan terhadap konsumen. Bagi PT. Mulia Wisata Perkasa, teknologi dapat berpengaruh positif dalam mengoperasikan usahanya.

Faktor-faktor Internal dan Ekternal PT. Mulia Wisata Perkasa

\section{IFAS PT. Mulia Wisata Perkasa}

Berdasarkan tabel 2 diketahui bahwa IFAS faktor internal strengths mempunyai total nilai skor 2 dan weaknesses mempunyai total nilai skor 1,22, yang artinya nilai kekuatan lebih tinggi dari nilai kelemahan.

\section{Tabel 2. IFAS PT. Mulia Wisata Perkasa}

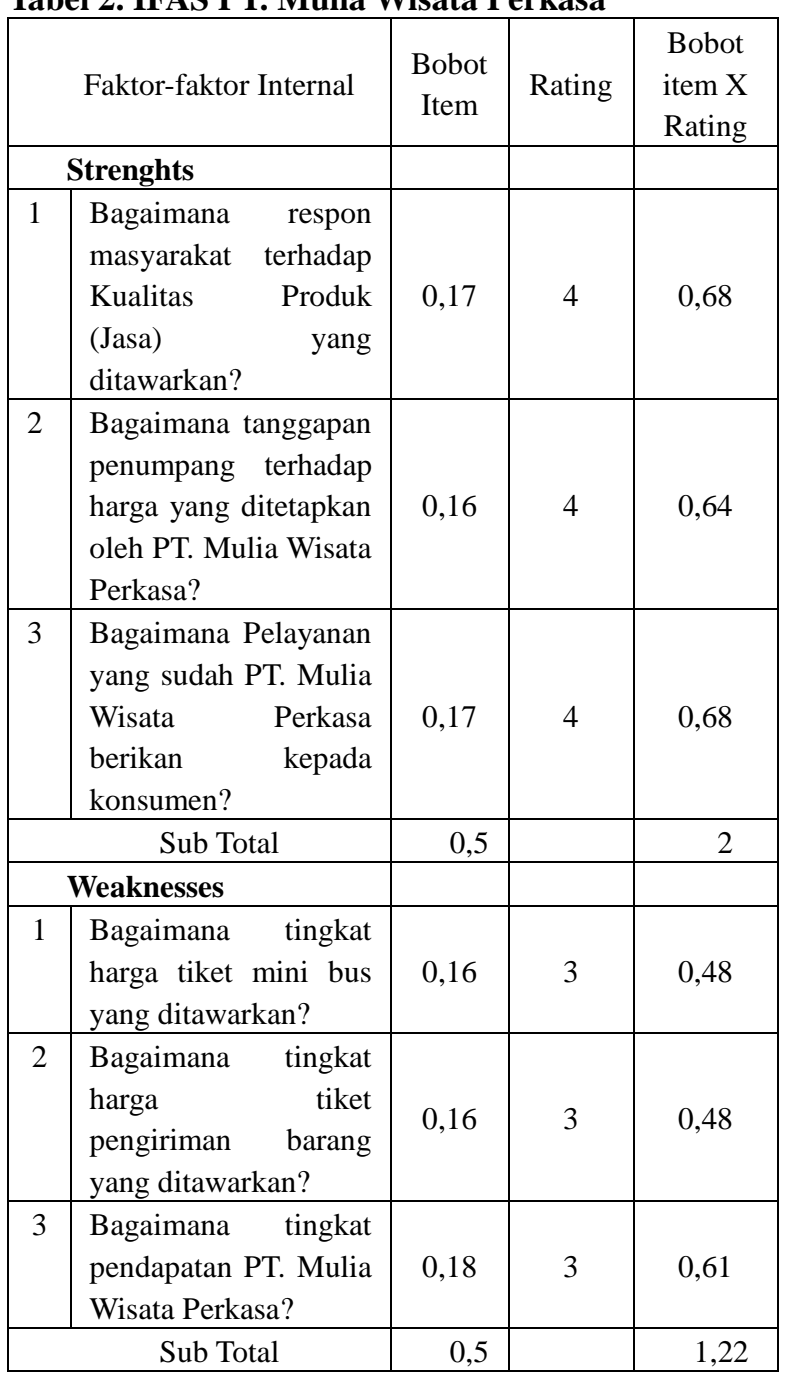

\section{EFAS PT. Mulia Wisata Perkasa}

Berdasarkan tabel 3, diketahui bahwa EFAS faktor eksternal oppurtunities mempunyai total nilai skor 1,63 dan threats mempunyai total nilai skor 1 , yang artinya nilai peluang lebih tinggi dari nilai ancaman.

Tabel 3. EFAS PT. Mulia Wisata Perkasa

\begin{tabular}{|c|c|c|c|c|}
\hline \multicolumn{2}{|r|}{ Faktor-faktor Eksternal } & $\begin{array}{c}\text { Bobot } \\
\text { Item }\end{array}$ & Rating & $\begin{array}{l}\text { Bobot } \\
\text { item X } \\
\text { Rating }\end{array}$ \\
\hline \multicolumn{5}{|c|}{ Opportunities } \\
\hline 1 & $\begin{array}{lr}\text { Bagaimana } & \text { tingkat } \\
\text { permintaan } & \text { pasar } \\
\text { terhadap PT. Mulia } \\
\text { Wisata Perkasa? }\end{array}$ & 0,175 & 3 & 0,60 \\
\hline 2 & $\begin{array}{l}\text { Bagaimana tanggapan } \\
\text { penumpang terhadap } \\
\text { jasa pengiriman } \\
\text { barang PT. Mulia } \\
\text { Wisata Perkasa? }\end{array}$ & 0,17 & 3 & 0,56 \\
\hline 3 & \begin{tabular}{lr} 
Bagaimana & citra \\
perusahaan & minibus \\
dimata & para \\
penumpang & selama \\
usaha PT. & Mulia \\
\multicolumn{2}{l}{ Wisata Perkasa? } \\
\end{tabular} & 0,155 & 3 & 0,47 \\
\hline \multicolumn{2}{|r|}{ Sub Total } & 0,5 & & 1,63 \\
\hline \multicolumn{5}{|c|}{ Threats } \\
\hline 1 & $\begin{array}{lr}\text { Bagaimana } & \text { tingakt } \\
\text { persaingan } & \text { yang } \\
\text { dihadapi PT. Mulia } \\
\text { Wisata Perkasa? }\end{array}$ & 0,16 & 2 & 0,32 \\
\hline 2 & $\begin{array}{lr}\text { Bagaimana } & \text { Tingkat } \\
\text { perkembangan } & \\
\text { perusahan } & \text { travel } \\
\text { minibus PT. } & \text { Mulia } \\
\text { Wisata Perkasa } & \\
\end{array}$ & 0,18 & 2 & 0,36 \\
\hline 3 & $\begin{array}{l}\text { Bagaimana kinerja } \\
\text { minibus secara teknis } \\
\text { terhadap kendala- } \\
\text { kendala dilapangan? }\end{array}$ & 0,16 & 2 & 0,32 \\
\hline \multicolumn{2}{|r|}{ Sub Total } & 0,49 & & 1 \\
\hline
\end{tabular}

Dari hasil identifikasi faktor-faktor tersebut maka dapat digambarkan dalam Diagram SWOT, dapat dilihat pada gambar berikut ini : 


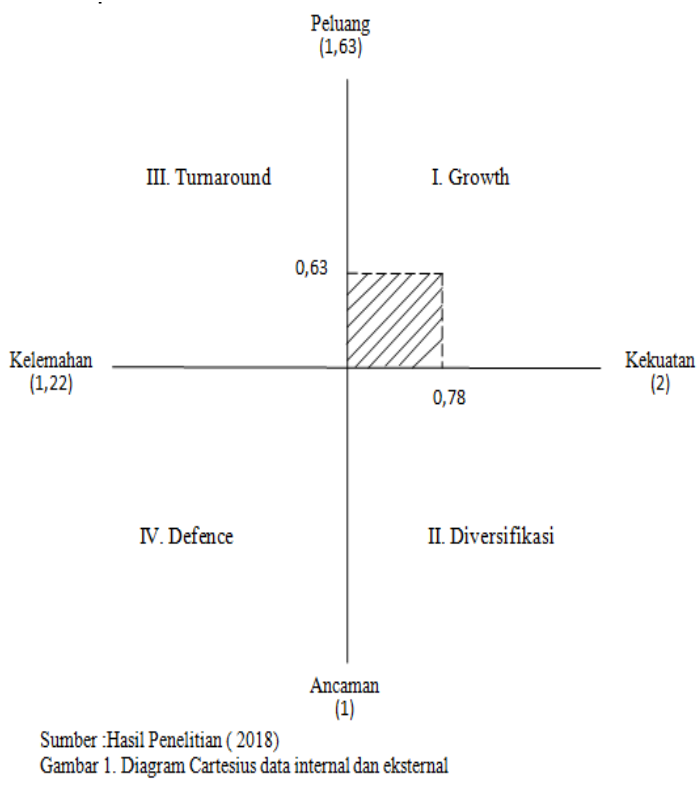

Berdasarkan gambar diagram diatas, nilai total skor dari masing-masing faktor adalah : nilai strengths 2 , weaknesses 1,22 , oppurtunities 1,63 dan threats 1. Maka dapat diketahui bahwa nilai strength melebihi atau diatas nilai weakness dengan selisih $0.78 \quad(2-1,22)$ dan nilai opportunity juga melebihi atau diatas nilai threat dengan selisih 0.63 (1,63-1). Jadi dapat disimpulkan bahwa PT. Mulia Wisata Perkasa telah berada pada jalur yang tepat dengan terus melakukan strategi growth (pertumbuhan). Strategi pertumbuhan ini merupakan strategi utama perusahaan dengan posisi pasar kompetitif yang kuat dalam industri yang berdaya tarik tinggi. Agar meningkatkan kekuatan bisnisnya, perusahaan harus melaksanakan upaya meminimalkan biaya operasional yang tidak efisien untuk mengontrol kualitas jasa yang diberikan.

\section{Strategi Utama}

Identifikasi pada faktor internal dan eksternal maka dapat menciptakan empat strategi utama, yaitu: strategi SO (strength dan opportunities), strategi WO (weakness dan opportunities), strategi ST (strength dan treats) dan strategi WT (weakness dan treats). Strategi tersebut dapat dijabarkan sebagai berikut :

1. Strategi SO (strength dan opportunities) Strategi ini dilakukan untuk memanfaatkan kekuatan perusahaan guna menangkap peluang yang dimiliki perusahaan.Memberikan promosi pada pasar konsumen yang diinginkan, memberikan jaminan kualitas terhadap produk (jasa) yang ditawarkan dan memberikan pelayanan yang maksimal kepada konsumen.

2. Strategi ST (strength dan treats)

Strategi ini diterapkan dimana kekuatan yang dimiliki perusahaan digunakan untuk mengatasi ancaman yang mungkin dapat dihadapi PT. Mulia Wisata Perkasa.menerapkan harga yang bersaing pada produk (jasa) yang ditawarkan, menambah jumlah mini bus (pembelian baru) dan menambah jumlah supir atau karyawan pada bagian yang mengalami kekurangan.

3. Strategi WO (weakness dan opportunities)

Strategi ini diterapkan pada saat adanya peluang yang dimiliki perusahaan guna mengatasi ancaman usaha. Perusahaan bisa menerapkan harga yang bersaing pada produk jasa yang ditawarkan, menambahkan rute perjalanan mini bus dan jumlah mini bus serta memberikan pengaman GPS pada 
setiap mini bus.

4. Strategi WT (weakness dan treats)

Strategi ini diterapkan saat perusahaan harus mampu mengatasi kelemahan yang dimiliki perusahaan agar terhindar dari ancaman usaha yang akan dihadapi. Perusahaan dapat menentukan harga yang kompetitif namun tidak merugikan bagi PT. Mulia Wisata Perkasa, meningkatkan keamanan pada mini bus yang dioperasionalkan dan memilih supir yang kompeten dan dapat dipercaya.

Strategi yang tepat diterapkan pada PT. Mulia Wisata Perkasa untuk saat ini adalah menerapkan strategi SO (strength dan Opportunities). Strategi SO (strength dan opportunities) ini dilakukan untuk memanfaatkan kekuatan perusahaan guna menangkap peluang yang dimiliki perusahaan dengan memberikan promosi pada pasar konsumen yang diinginkan, memberikan jaminan kualitas terhadap produk (jasa) yang ditawarkan, dan memberikan pelayanan yang maksimal kepada konsumen.

\section{KESIMPULAN DAN SARAN}

\section{Kesimpulan}

Berdasarkan hasil penelitian, maka penulis dapat memberikan kesimpulan sebagai berikut:

1. Tingkat permintaan pasar baik, tanggapan penumpang baik dan citra perusahaan yang baik menuntut perusahaan untuk selalu membuat perubahan baru guna mendapatkan citra di mata para konsumen mini bus PT. Mulia Wisata Perkasa.

2. PT. Mulia Wisata Perkasa telah berada pada jalur yang tepat dengan terus melakukan strategi growth (pertumbuhan), berdasarkan diagram cartesius.

3. Strategi yang tepat diterapkan pada PT. Mulia Wisata Perkasa untuk saat ini adalah menerapkan strategi SO (strength dan Opportunities). Strategi SO (strength dan opportunities) ini dilakukan untuk memanfaatkan kekuatan perusahaan guna menangkap peluang yang dimiliki perusahaan. Memberikan promosi pada pasar konsumen yang diinginkan, memberikan jaminan kualitas terhadap produk (jasa) yang ditawarkan dan memberikan pelayanan yang maksimal kepada konsumen.

\section{Saran}

1. Berdasarkan hasil penelitian dan pembahasan penulis diatas, adanya pesaing liar yang beredar di sekitar tempat usaha PT. Mulia Wisata Perkasa bisa berdampak buruk terhadap operasional Mini Bus PT. Mulia Wisata Perkasa, oleh karena itu, diharapkan lebih waspada dalam menjalankan usaha tersebut.

2. Penelitian yang telah kami lakukan ini, diharapkan juga menjadi bahan referensi pelengkap bagi penelitian yang akan dilakukan selanjutnya, dan peneliti 
selanjutnya agar dapat menggunakan metode dan variabel lain dalam menganalisis manajemen transportasi (darat, laut, dan udara).

\section{DAFTAR PUSTAKA}

Andriansyah. (2015). Manajemen Transportasi Dalam Kajian dan Teori. Fakultas Ilmu Sosial dan Ilmu Politik Universitas Prof.Dr. Moestopo Beragama.

Hasibuan, Malayu S. P (2007). Manajemen Sumber Daya Manusia Perusahaan. Bandung : PT. Bumi Aksa.

Kamaluddin. (2003). Ekonomi Transportasi. Jakarta. PT. Ghalia Indonesia.

Manullang, M. (2006). Dasar-Dasar Manajemen. Yogyakarta : Gajah Mada University Press.

Marpiani. (2011). Peranan Transportasi Pedesaan Terhadap Peningkatan Hasil Produksi Pertanian di Kecamatan Kindang Kabupaten Bulu Kumba. Fakultas Sains dan Teknologi Universitas Islam Negeri Alauddin Makassar. Skripsi.

Nasution, M.N. (2004). Manajemen Jasa Terpadu. Jakarta : PT. Ghalia Indonesia.

Nugroho, H. (2008). Kelayakan Reformasi Sistem Transportasi Angkutan Umum. Perkotaan di Provinsi Daerah Istimewa Yogyakarta. Tesis (tidak dipublikasikan).

Rangkuti, Freddy. (2006). Analisis SWOT:

Teknik Membedah Kasus Bisnis. Jakarta. PT Gramedia Pustaka Utama.

Ratnasari T. Ririn., Mastuti H Aksa. (2011).

Manajemen Pemasaran Jasa. Penerbit:

Ghalia Indonesia.
Setiani, Baiq. (2015). Prinsip-prinsip Pokok Pengelolaan Jasa Transportasi Udara. Jurnal Ilmiah WIDYA. 3(2).

Silalahi, L. Ganda. (2011). Analisa Pemilihan Moda Transportasi Bus Dengan Metode Stated Preference (Studi Kasus MedanSidikalang). Skripsi Teknik Sipil USU, Medan

Solihin, Ismail. (2009). Pengantar Manajemen. Jakarta : Erlangga.

Sukarto, Haryono. (2006). Transportasi Perkotaan dan Lingkungan. Jurusan Teknik Sipil-Universitas Pelita Harapan. Banten.

Terry, George., Leslie W. Rue. (2010). DasarDasar Manajemen. Cetakan kesebelas. Jakarta: PT Bumi Aksara.

- How to cite this paper :

Sarafina, R., Usman, B., \& Adamy, Y. (2019). Analisis Manajemen Transportasi Pada Angkutan Mini Bus. Jurnal Humaniora, 3(1), 1-13. 